\title{
Belphégor
}

Littérature populaire et culture médiatique

$17 \mid 2019$

Mutations des légitimités dans les productions culturelles contemporaines

\section{Kashtan, Aaron. Between Pen and Pixel: Comics, Materiality and the Book of the Future}

\section{Chris Reyns-Chikuma}

\section{(2) OpenEdition}

\section{Journals}

Electronic version

URL: https://journals.openedition.org/belphegor/1497

DOI: $10.4000 /$ belphegor.1497

ISSN: 1499-7185

Publisher

LPCM

Electronic reference

Chris Reyns-Chikuma, "Kashtan, Aaron. Between Pen and Pixel: Comics, Materiality and the Book of the Future", Belphégor [Online], 17 | 2019, Online since 18 April 2019, connection on 25 August 2021. URL: http://journals.openedition.org/belphegor/1497 ; DOI: https://doi.org/10.4000/belphegor.1497

This text was automatically generated on 25 August 2021.

\section{(c)}

Belphégor est mis à disposition selon les termes de la Licence Creative Commons Attribution - Pas d'Utilisation Commerciale - Pas de Modification 4.0 International. 


\section{Kashtan, Aaron. Between Pen and} Pixel : Comics, Materiality and the Book of the Future

Chris Reyns-Chikuma

\section{REFERENCES}

Kashtan, Aaron. Between Pen and Pixel : Comics, Materiality and the Book of the Future. OSU. Press, 2018. 


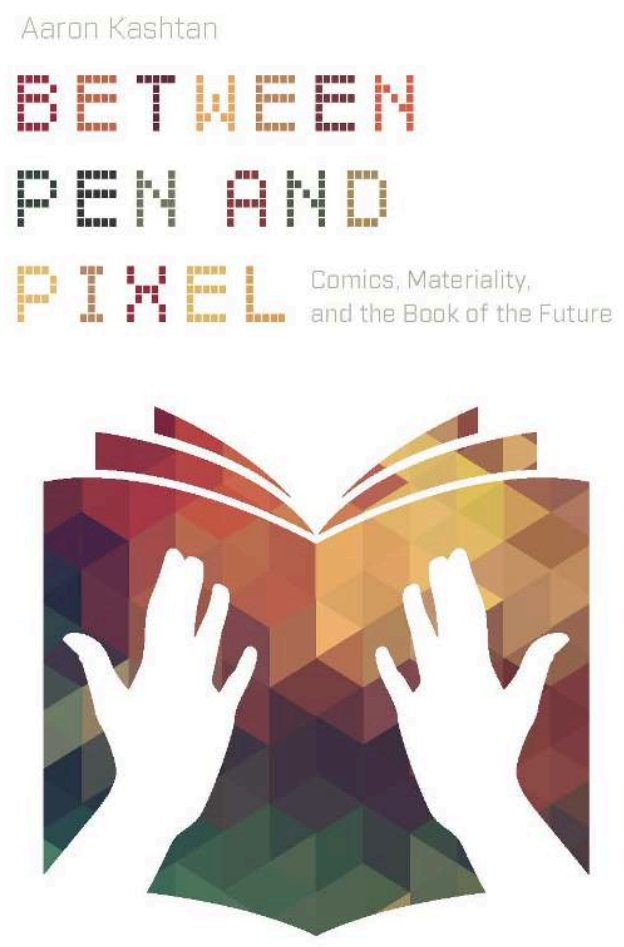

1 Aaron Kashtan's latest book, Between Pen and Pixel: Comics, Materiality and the Book of the Future, is the 14th in the series "Studies in Comics and Cartoons", edited by renowned comics scholars Jared Gardner (Projections, 2015) and Charles Hatfield (Alternative Comics, 2008). Other prestigious contributors to this series include the likes of Frederick Luis Aldama (2018), Marc McKinney (Redrawing French Empires, 2013), and Robert Harvey (A Gallery of Rogues: Cartoonists' Self-Caricatures, 1998). Notably, publications in the series "focus exclusively on comics and graphic literature, highlighting their relation to literary studies. It includes monographs and edited collections that cover the history of comics and cartoons from the editorial cartoon and early sequential comics of the 19th century through webcomics of the 21st. Studies that focus on international comics are also considered" (211).

2 Between Pen and Pixel is the first study in this collection focusing on electronic comics. And, as highlighted by the description of the series, it focuses on the relationship between e-comics and literary studies, with specific attention to their materiality. Kashtan's original viewpoint is to step beyond the binary opposition between nostalgia for the printed book and its supposedly inherent humanistic values (as famously argued by Sven Birkets, Andrew Piper, and Nicholas Carr), and the utopian perspective on electronic text (as argued by the hypertextual scholars-writers like George Landow, Jay Bolter, and Michael Joyce). He convincingly demonstrates through the five chapters that the comic book is actually a serious possible model for the book of the future. The book's future format would not only be textual like most books since the Gutenberg revolution, but also incorporate a smart dynamic mixture of texts and pictures, similar to what we have on the web. To support his argument, Kashtan uses a very convincing analyses of various "comics". For example, in chapter 1 he interprets sections from Alison Bechdel's Fun Home; in chapter 2 he presents examples from Carla Speed McNeil's Talisman, Lynda Barry's Syllabus and Matt Kindt's Mind MGMT; and chapter 3 features excerpts from Randall Munroe's $x k c d$-"Click and drag" as well as some other 
webcomics. In chapter 4, Kashtan draws examples from Alex Robinson's Box Office Poison, Dan Slott and Mike Allred's Silver Surfer, and Paul Tobin and Colleen Coover's Bandette; and in the final chapter, Kashtan completes his analysis with examples from Chris Ware's Building Stories, Jason Shiga's Meanwhile and Amaranth Borsuk and Brad Bouse's Between Page and Screen.

From the onset, Kashtan plays what seems to be a bit of the Devil's advocate to illustrate how Bechdel's attitude against digital technologies is not as simple as it might appear first. This negativity towards the digital first appears in Bechdel's stated intentions (as documented in interviews) and is then again emphasised through interpretations of several passages in her book. However, a closer reading of the formal, social and material aspects of the book brings to light a partial contradiction to that negativity. In effect, everything in Fun Home seems to place the unique, handwritten, handmade book in opposition to the machine-like, inhuman, common, commercial, printed books and digital technologies. However, through a very detailed analysis of every reference to handwriting and books, Kashtan convincingly shows that praise for handwriting and the belief that it is the embodiment of the deep soul of the writer/creator, is much more nuanced. First, in Bechdel's book, handwriting "serves as a vehicle for concealing rather than revealing an uncomfortable truth about the self" (34). Complementarily, typewriting is not as disembodied as it seems - first, because it has been socially associated with women's jobs (as secretary, as opposed to stenography associated with men); second, it is associated to Alison's mother's typewriter (38); and third, as any good detective story would tell us, every typewriter has its own peculiar imprint and Bechdel carefully identify what kind of typewriter each character uses in the story (36). Moreover, what seems handwritten by Bechdel was actually typewritten (40), and as a book the handwriting is actually printed (hence, mediated). Therefore, Bechdel's book is not a uniquely crafted art book, nor is it like Barry's books which emphasize a book's materiality (see chapter 4). Further on in the book, Kashtan points out that instead of actual contact between writer/artist and readers, comics offer an experience of "haptic visuality", that involves a close-up and tactile way of looking in which "the eyes themselves function like organs of touch" (Marks cited p. 41). In comics however, the reader also has to touch the book in order to read it (e.g., to turn the pages). Therefore, there is an interplay between actual and apparent touch (or between "formal and forensic materiality"-Kirschenbaum cited $\mathrm{p}$. 42).

4 Furthermore, Kashtan demonstrates how Bechdel criticizes the fetishistic attitude of Alison's father Bruce, who collects expensive texts and uses these auratic books to "create his constructed persona", a "“fantasy' albeit 'a fully operational one"' (47). Finally, Kashtan gives an example taken from the electronic version of Fun home, to emphasize what has been well-known in translation - that when you translate you may lose something but you might also gain something else in return. For example, with the transfer of Fun home to the Amazon Kindle, pages 100-101 are no-longer located where they were in the printed version, that is, at the exact center of the book - which is symbolically the "'centerfold', as in the Playboy sense and also representing a meeting point between Alison and Bruce." Since Fun Home is a "notoriously nonlinear text" the e-book version allows a reading where "no single page enjoys absolute priority as the beginning or the center of the narrative" (52). As a result, the reformatted e-book version may produce new readings. 
5 In chapter 2 (54-90), Kashtan examines how print comics have responded to the perceived threat posed by digital comics. McNeil's Talisman is used as a negative example of how print comics can advocate for the superiority of the print medium (56). Talisman does not go far enough and does not take advantage of the crisitunity (crisis as opportunity) ${ }^{1}$ offered by the threatened status of print (65). Kashtan also points out that Talisman is a typical example of "biblionecrophilia", a term used to define "the retreat of the print faithful into a sort of autistic fetishization of the book-as-object" (Ehrenreich cited p. 54).

6 Barry's Syllabus also sees the printed book as a magical object. Through its concrete, material, and practical characteristics such as handwriting, drawing and bookmaking, it demonstrates how the commitment to bibliophilia can be translated into actual bookmaking that is "using the material properties of comics to create meaning" (65). Kashtan notes that generally Barry also sees "the physicality of writing as a means of creating "muscle memory"' (71) especially since writing and drawing are physical as well as mental activities, and they "require practice just as other physical disciplines do" (72). Hence, in Barry's case, the "human body is always already technological" (72). Kashtan then inscribes Syllabus within a critical tradition that is both artistic-academic, with Johanna Drucker's The Visible Word as and example, and fictional, by featuring numerous examples of poetry and fictions. These fictional cases play with the multimodality and materiality of the text/book produced by modernist and postmodernist avant-garde creators, like Apollinaire's Calligrammes (in the 1910s), Borges' "El jardín de senderos que se bifurcan ["The Garden of the Forking Paths"] (1944), Queneau's "Un Conte à votre façon [A Tale as you like]" (1967) and Cent mille milliards de poèmes ([Hundred Thousand Billion Poems], 1961), Cortázar's Rayuela [Hopscotch], 1963), Theresa Hak Kyung Cha's Dictée (1982), and the more recent examples of Jennifer Egan's A Visit from the Goon Squad (2011), ... Further into the chapter, Kashtan discusses how a graphic novelist can "Kindle-proof [his/her] comic in seven easy steps" (76). He also uses Matt Kindt's "higher-end segment of the commercial" (80) comic book series Mind MGMT, published by Dark Horse that started in 2012, as a convincing example of Kindle-proof comics that "resist translation into digital form because their meanings are inextricably linked to their physical properties" (90). ${ }^{2}$

7 Chapter 3, “'Click and drag': The Continuing Relevance of Print to Digital Comics" (91-110), starts by relativizing McCloud's forecast of a post print future for comics with the new digital offers such as interactivity, sound, moving images, and the "infinite canvas" (see his Reinventing Comics, 2000). However, more than 15 years after Mccloud's prediction, many webcomics still do not employ digital specific features. One factor that is made evident, is that some comics, especially the non-specific digital comics, are easily transmediated to various formats of print, and others are not. Such is the case of Charles Schultz' Peanuts (93-94) which is easily reformatted. This is because, as Noah Berlatsky emphasized, some comics are spatially flexible (as Charles Schultz's) and others are spatially fixed (such as Winsor McKay's).

8 It is also pointed out that webcomics, that have specific digital techniques, still make sophisticated use of tactile functionality. As demonstrated by Ian Hague ${ }^{3}$, touch plays a central role in comics. Of course, in the digital world, one might see constraints associated with the physical form of comics. For example, tactility and the shape of the page, are sources of friction (98), but as shown by writers and artists (most of them 
cited in the previous summary of chapter 2), constraints can be productive. And some e-comics artists have created works seeking "to use the possibilities of the digital interface to create 'good friction' [...] rather than remove friction entirely" (98); Randall Munroe's e-comic $x k c d$ is a good example (99-102).

Moreover, books still sell well, and even more surprisingly, books from webcomics are in demand by readers, including e-comics readers. Their sales are supported for various reasons including emotional and financial support for a favorite artist, because webcomics are mostly free (since the micropayment model failed, p. 104) so the fan purchase of a physical book can provide the author/artist with an income. There are also collectors who prefer concrete objects to digital files. And finally, fans also buy the book version to share as a gift (something more difficult to do with a free webcomics!).

The fourth chapter, "Guided View: How Comics Move from Print to Digital and Back" (111-136), discusses how comics can be designed for flexibility but electronic technologies are not yet making the translation from print easy. The Text Encoding Initiative (TEI) is effective for translating print texts into digital form, but does not work well for images, especially comics images. This is due to the fact that one of the fundamental design elements of comics is the page. As shown by Thierry Groensteen, the margin of the page can sometimes have a compositional function. The American (and Western) book pages are typically published in portrait orientation while computer screens are characteristically published in landscape orientation (114). Tablet devices, starting in 2010, allowed the reader to switch to a vertical format, but it was, and still is, often too small, impairing the reading/viewing of words and details on a whole page. Comixology (acquired by Amazon in 2014) then created a guided view tool enabling readers to view comic pages panel-by-panel. If the comics panels are vertical it works quite well. But not all panels are rectangular and not all pages use regular panels such as in the case of Alex Robinson's Box Office Poison, (118-119). Kashtan gives the example of the most audacious experimental comics in the commercial comics industry (Silver Surfer by Marvel) where authors Allred and Slott meaningfully designed some pages in a Möebius strip format (122-124). This digital version offers a comparatively impoverished reading experience; however, it has to be emphasized that this is not because of an inherent impossibility of the technology, but because it "was not cost-effective": "there was no financial incentive to produce a more faithful digital version of it" (128).

11 The print publication of a digital version is published only if it can find an audience. This is the way Monkeybrain comics works. Bandette is an instructive example of the development of a project that can move from print to digital form and back (130). It is the story of a young supergirl. It is explicitly inspired by French Bande dessinée and the French 1910s best seller "Arsene Lupin gentleman cambrioleur" [thief gentleman]. ${ }^{4}$ But it could not easily find a publisher; first, because it pertains to the superhero genre, second, the heroine is a thief (although a good person), and third, it has a lighthearted and humorous tone. Bandette was nominated for four Eisner Awards in spite of being in the category of digital comics (131), and was then published in a print pamphlet size comic book format. Because it uses a three-tier panel with rectangular borders, it adapted well to the guided view technology. The printed version also offers added value to enhance the reading experience through its publication design, the bookplate [to write its owner's name], and additional short stories in prose, illustrated or not, and 
some graphic short stories. The printed version therefore is intended to complement rather than replace the digital edition.

In chapter 5, "Between panel and screen: Comics that are print and digital at once" (137-184), it is argued, and shown, that the oppositional approach to the print/digital debate is unproductive. Kashtan feels that it is more productive to conceive them as complementary rather than as oppositional terms. The first part of the chapter focusses on Chris Ware's Building Stories. It is a box containing 14 different items telling part of his protagonist's life in various forms of printed medium (floppy pamphlet, newspaper page, hardcover album style). This "comics" has been considered the acme of biblionecrophilia, a publication strongly nostalgic for the book-print period, but one more time Kashtan shows that it is more nuanced. Ware is not the only one to use technology such as scanning for editing and coloring. However, this "comics" is not a book, it is a box with a playful format that is closely related to the interactive forms of hypertext (like Michael Joyce's Afternoon, 1992, and Shelley Jackson's The Patchwork Girl, 1999) freed of the codex book. Even if it is still a format that asserts the materiality of the medium, by having the readers go through a concrete manipulation of the various printed items, some elements indicate an opening to e-comics formats. The first of these elements is in the content since protagonist asserts that her prosthetic left leg is just as much 'hers' as her right natural leg.

13 Even more interesting is that Ware originally published one part of the puzzle in electronic format created for the McSweeney's iPad app. It is entitled "Touch Sensitive" and directly addresses the issue of touching since it is the story of the deterioration of a marriage described through the loss and lack of touching in the couple. Ware explained that he "tried to use touch-sensitivity as a poetic metaphor for how we manipulate our memories [...] and the act of touching in a relationship gradually goes from one of tenderness and affection to one of anger and dominance" (cited 161). Although the first version ended negatively, he later added a sequence suggesting that "there was still a possibility of genuine contact between husband and wife" (163). The fact that the reader has to touch the screen to make the story progress compensates for the loss of materiality that the box-book building stories gives to the reader (166).

14 The second part of this chapter 5 focuses on Shiga's Meanwhile (2001; color 2010). Kashtan shows how Shiga, who graduated in "pure mathematics" from U. Berkeley, was from the beginning interested first in mathematical elements (game-like, ludic problems), and secondly he was absorbed by materiality since he started his comics "career" by creating minicomics, that is, do-it-yourself comics. Meanwhile is a "chooseyour-own-adventure" comics. But instead of using numbered sections or pages, Shiga invites the reader to follow lines or trails leading from one panel to another. This produces a complex web that creates "restricted arthrology" (Groensteen) which operates at the level of individual panels and sequences, but also "general arthrology" linking panels that belong to different sequences (172). This trail technique incorporates tabs, like those found in some encyclopedias, which in turn create a threedimensional object. Interestingly, Shiga's "choose- your-own-adventure" books declined in popularity and then virtually disappeared in the 1990s due to competition from digital media (e.g., videogames). Andrew Plotkin, a prominent author of text adventure games, proposed to Shiga to recreate the adventures in digital format. Shiga accepted, and it was distributed in November 2011 by Zarfhome software consulting, whose offerings consist mostly of Plotkin's highly literary and experimental works of 
interactive fiction. Meanwhile suggests a model of digital and print synergy (182). The chapter concludes with an "almost-comic" titled Between Page and Screen (by Amaranth Borsuk and Brad Bouse in 2016). It requires both media - print and electronic - to be used in tandem in order to unlock its meaning (182).

The book's "Conclusion", “Applications for Studying and Teaching Comics" (185-193), provides advice on how to apply the previously mentioned books and examples in teaching situations. As referenced throughout the book, Kashtan draws on his own experience as an instructor in the university writing program at the university of North Carolina at Charlotte to provide concrete ways to introduce comics into the classroom.

To briefly conclude this long book review, Kashtan's study is extraordinarily interesting and useful for all lovers and scholars of books in any format (manuscript, print and electronic). It is well written, well documented, with very concrete and convincing analyses, and followed by a good index and a good bibliography.

\section{NOTES}

1. a pun-portemanteau word explained, humorously, in the text as "a Chinese word that (according to the noted scholar Homer J. Simpson) means both 'crisis' and 'opportunity"' (55).

2. In a footnote, Kashtan cites French Marc-Antoine Mathieu's Julius Corentin Acquefacques as an "ultimate example" but does not discuss it since "the scope of this book is limited to Englishlanguage comics" (76).

3. Ian Hague, Comics and the Senses: A Multisensory Approach to Comics and Graphic Novels, 2014.

4. Moreover, what is not said by Kashtan or by the two authors, the story is most probably also influenced by the French 1960s bestseller story Fantomette. 